\title{
Improving Discipline Analysis of High School Students with Guidance and Counseling approaches
}

\author{
Lita Gustiana ${ }^{1}$, Daharnis ${ }^{1}$, Marjohan ${ }^{1}$ \\ ${ }^{1}$ Universitas Negeri Padang. \\ *Corresponding author, e-mail: litagustianaunp2017@gmail.com
}

\begin{abstract}
Discipline is defined as the compliance with existing rules or regulations with pleasure and selfawareness. It has a huge influence on learning, personal interest, social life and career of students. Therefore, the purpose of this study is to describe the disciplinary problems of students at SMAN 2 Padang and ways to improve it using the right counseling approach. Data was analyzed using the quantitative and descriptive methods with a reliability scale of 0.909. The research findings shows the discipline of students in SMAN 2 Padang is in the sufficient category with a percentage of 79.27\% in accordancewith established rules. Therefore the Rational Emotional Behavior Therapy group format approach is developed to enhance the problem of proper student discipline.
\end{abstract}

Keywords: Student Discipline, Rational Emotive Behavior Therapy

How to Cite: Gustiana, L., Daharnis, D., Marjohan, M. 2019. Improving Discipline Analysis of High School Students with Guidance and Counseling approaches. International Journal of Research in Counseling and Education, 4(1), 9-14

\section{Introduction}

Discipline is very important and needs to be applied by students to improve learning achievement (Wisnu \& Kurniawan, 2007; Riyadi, 2011; Fiana, Daharnis, \& Ridha, 2013; Ariananda, Hasan, \& Rakhman, 2014; Yanti \& Rosalina, 2016). It is formed as a result of the coaching process carried out in the family environment and continued in schools which is an important place for its enhancement(Wulandari, Zikra, \& Yusri, 2017). It improvesin stages with the help of the guidance and counseling teacher as an educator (Dani, Suarni, \& Sulastri, 2013; Afdal, 2015).

Furthermore, it is related to the moral attitudes applied in groups, which requires an element of volunteerism supported by self-awareness. This means that the willingness and ability to behave according to the rules agreed by the group arises without coercion (Aulina, 2013; Amri, 2013; Ernawati \& Afdal, 2018; Agustina, Daharnis, \& Hariko, 2019).

According to Aulina, the purpose of discipline is to form the right behavior in accordance with the roles that apply in the group (Aulina, 2013). Humphreys, Weber, \& Yavuzer, (Sadik, 2017)stated that its purpose is to develop responsibility and self-controlled skills by supporting mental, emotional and social development. A disciplined attitude creates a conducive learning atmosphere at school (Tu'u, 2012; Natalia, Firman, \& Daharnis, 2015).

Hurlock (2013) described four main elements of discipline namely; (1) rules, which are patterns established by teachers or playmates, with the purpose of equipping students with school and home rules; (2) punishment, which includes blocking the repetition of undesirable actions by the community, educating children to distinguish between right and wrong, and providing motivation to avoid unacceptable behaviors; (3) appreciation for a good resultin the form of words of praise, a smile or a pat on the back and (4) consistency, which is the level of uniformity or stability which does not change.

Durkheim (1990)stated that some characteristics of student discipline in school include adhering to rules, carrying out their educational duties, regularly attending classes, arriving at the appointed time, conducting homework and not making fusses. Similarly, Susilowati (2005)stated that obedience, loyalty, regularity, order, commitment, and consistency are some of the characteristics of disciplined students.

The aspects of discipline include (1) proper utilization of time, which means students need to get acquainted with managing time in daily life, from small acts such as arriving early to school; (2) adhering to schedule and motivation to learn at school and home, such working on assignments given by the teacher and (3) discipline in manners which is related to morals or ethics of students, to teachers, friends and the 
community (Semiawan, 2008).

The next aspect of discipline is dressing, because students tend to feel uncomfortable when not in the right clothes. Discipline in dressing plays an important role in education owing to its ability to develop students potential and personality in line with academics and other aspects of life. Student's need to inculcate the habit of being neat, in accordance with applicable regulations (Pratama,2013).

Learning discipline is very important and influences students' academic learning outcome (Daharnis, Erlamsyah, Ifdil, Ardi, \& Hariko, 2013; Fitri, Ifdil, \& Neviyarni, 2016; Wulandari et al., 2017). However, not all students are disciplinewhich leads to problems such as disruptive classroom behaviour, vandalism, bullying, and violence (Luiselli, Putnam, Handler, \& Feinberg, 2005). It is also associated with disturbing friends, damaging school facilities, difficulty in focusing attention, pondering, and skipping classes(Netrawati, Karneli, \& Neviyarni, 2018).

According to the National Center for Education Statistics (2018), discipline problems occurred in schools during between 1999-2000, 2009-10, and 2015-16.The School Survey on Crimes and Safety (SSOCS) on discipline problems in schools are seen in figure 1:

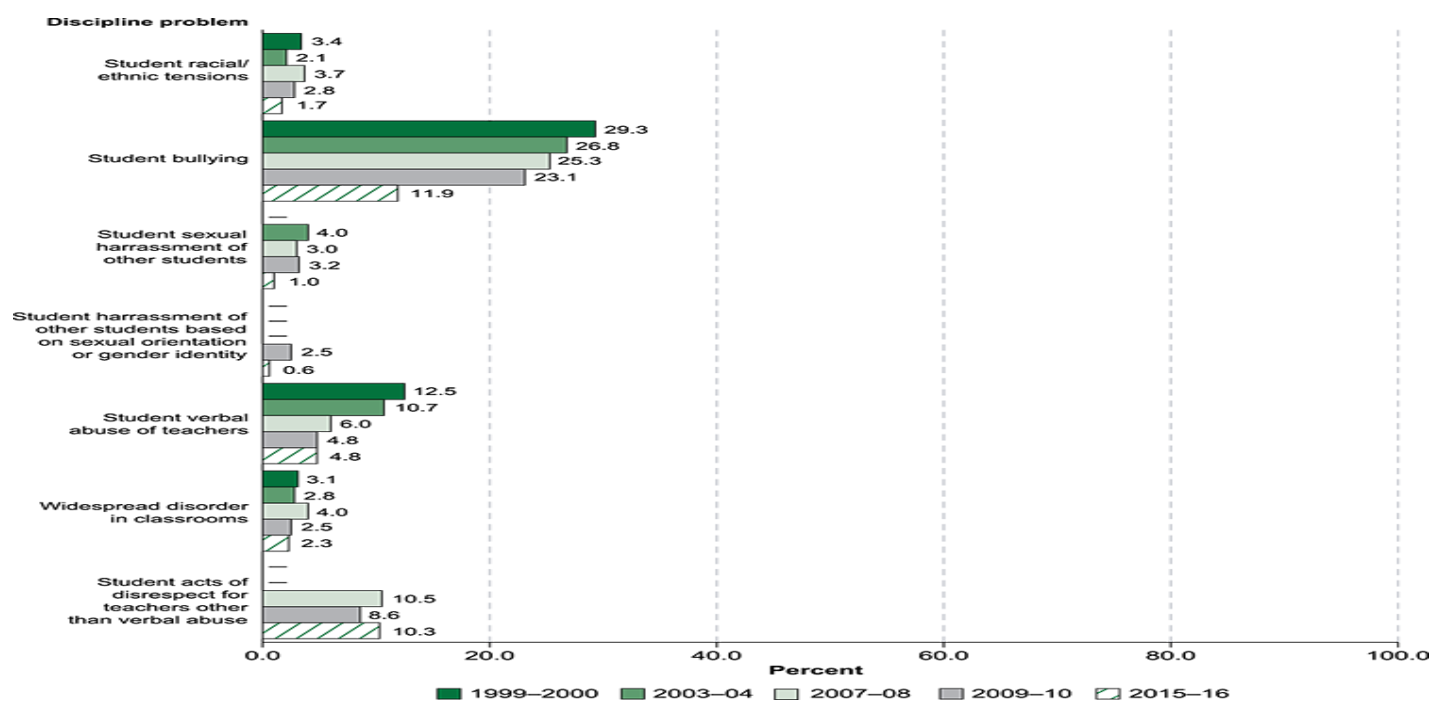

Figure 1. Percentage of public schools reporting selected discipline problems which occurred at least once a week between $1999-2000$ and 2015-16

In 2015-16, approximately12 percent of public schools reported that bullying occurred among students at least once a week, with 5 percent reporting of student verbal abuse to teachers. Furthermore, 10 percent reported acts of student disrespect on teachers other than verbal abuse,2 percent analyzed widespread disorder in the classroom and student racial/ethnic tensions, and 1percent each reported sexual harassment of other studentsbased on sexual orientation or gender identity. Finally, 10 percent of public schools reported that gang activities occurred during the 2015-16 school year.

Lack of discipline is a problem constantly faced by teachers in the classroom (Geiger, 2000), whichsometimes leads to series of riots, and destruction of school property (Salgong, Ngumi, \& Chege, 2016). According to Sadik, low student discipline cause stress for educators (Sadik, 2017). Research by Bechuke \& Debeila (2012) found that teaching and learning processes are hampered when student behavior interferes. According to the management of SMA Negeri 6, Bulungan, Jakarta Selatan, 42 students were expelled from the institution due to violations of the school code of conduct which resulted in the death ofa class $X$ student(Putra, 2012).

Some of the disciplinary problems which currently occur in SMAN 2 Padang are as follows: students arrive late, leave classes at the change of time, wear shoes other than black, take off their clothes, fail to wear uniforms on specified days, skip classes, and pile up or ignore assignments given by the teacher. Based on the above problems adequate discipline analysis are requiredto determine the best solution.

\section{Method}

This is a descriptive study which aims to describe and increase the discipline of high school students using the right counseling approach. The population of the study was 62 students selected from a total of 245 people using the purposive sampling techniques. Data collection instruments are in the form of student 
discipline scale with the procedure used to administer student discipline instrument to the research sample. Furthermore, the collected data is analyzed using percentage techniques.

\section{Results and Discussion}

Overall, a description of student discipline as seen in Table 1.

Table 1. Overview of Student Discipline

\begin{tabular}{llcc}
\hline No & \multicolumn{1}{c}{ Indicator } & $\begin{array}{c}\text { Average of Ideal } \\
\text { Score }\end{array}$ & $\%$ \\
& & 3,95 & 79,04 \\
2 & Discipline in Utilizing Time & 3,70 & 73,85 \\
2 & Discipline in Learning & 4,14 & 81,97 \\
3 & Discipline in Manners & 4,47 & 92,56 \\
4 & Discipline in Clothing & 3,97 & 79,27 \\
\hline
\end{tabular}

Based on the table above, it can be seen that the overall picture of student discipline is in the high category with a percentage value of $79.27 \%$ of the ideal score.

\section{Discipline in Utilizing Time}

The average percentage of student discipline in utilizing time was $79.04 \%$. However, compared to the rules in SMAN 2 Padang, not all students 'scores are in accordance with the expected result, because some of the valuescontained in a time dimension are in the sufficient category. The code of conduct which emphasizes norms or valuescontained in Chapter III article II concerning attendance includes; (1) teaching and learning process starts at $06.45 \mathrm{WIB}$ until $14.20 \mathrm{WIB}$ (according to schedule) and (2) students are not allowed to enter later than 06.50 WIB. In line with the opinion of Semiawan (2008) students need to learn how to manage time in daily life. This time arrangement starts from small acts such as coming on time to school, not playing truant etc. Student discipline problems which are identified and require special attention include problems associated with the following; (1) when changing class hours, (2) lateness to school and (3) lateness in carrying out extracurricular activities.

\section{Discipline in Learning}

Student discipline scores in studying reached an average percentage of $73.85 \%$,and when compared with the community rules it fails to match the expected result. This means that discipline scores in learning are in the sufficient category. Hurlock (2013) statedthat the discipline of learning are as follows: (1) obedient to discipline in school, (2) preparation of student learning, (3) attention to learning activities, and (4) completing assignments. However, the discipline problems of students at SMAN 2 Padang needs the following special attention: (1) before learning students do not learn the material taught by the teacher, (2) they tend to ask permission to leave the classroom or carry out other activities when learning is not interesting, (3) they tend to postpone work or homework, and (4) students are in a hurry when conducting assignments. The results of the research on attitude of learning discipline experienced by students has a positive relationship with achievement (Wisnu \& Kurniawan, 2007). Riyadi (2011) found a positive and significant correlation between learning discipline and student achievement. Furthermore, Ariananda, et al (2014) research found that student discipline in school had an influence on their achievement. This is reinforced by Yanti \& Rosalina (2016)research findings which stated that discipline had a significant relationship with learning achievement,therefore, it is necessary to handle its problems in learning (Reski, Taufik, \& Ifdil, 2017).

\section{Discipline in Manners}

Discipline in manners is a customary courtesy which is agreed upon in a social and school environment among community members and students. In terms of manners, it had an average percentage value of $81.97 \%$ which means that these students apply it to morals and ethics (Semiawan, 2008).

\section{Discipline in Clothing}

Discipline of students in clothes is in the high category, this is evidenced by the percentage value of 92.56\%. In accordance with its rules, the scores owned are above the applicable standards at SMAN 2 Padang, which means it is in line with applicable rules and regulations. Therefore, it is believed that students feel comfortable in the learning process. Pratama (2013)asserts that schools without discipline in dressing 
interfere with students' comfort asit plays an important role in education as well as the development of potential and personality.

\section{Improving Student Discipline}

Problems associated with student discipline in compliance with school rules and attitudesarise during violation. Yusuf (Fachrurrozi, Firman, \& Ibrahim, 2013) explained that student discipline is a problem that need to be immediately solved, it is of sufficient frequency to determine success. Froggatt (2005) explains almost all emotions and behavior of students is the result of what individuals think, or believe about themselves, others, and the world at large.

The problem of irrational beliefs and behavior of students is one of the factorsleading to the emergence of discipline problems. Hamalik (2011) clarified these factors as follows: internal factors, which are sourced from within the students by the implications of self-development such as unsatisfaction, lack of intelligence, memory or excessive energy and, external factors, which are sourced from the attitude of teachers and other school personnel.

Guidance and Counseling Services have approaches in order to improve student discipline, one of which is through the Rational Emotive Behavior Therapy approach which aims to improve and change beliefs, ways of thinking, attitudes, perceptions, and irrational views for students to develop themselves and achieve optimal self-realization(Corey, 2013).Rational Emotive Behavior Therapy tends to change students' irrational ways of thinking (Allen, K. R., \& Bradley, 2015; De Vries, S. L., Hoeve, M., Assink, M., Stams, G. J. J., \& Asscher, 2015; Konadi, Mudjiran, \& Karneli, 2017; Netrawati, Khairani, \& Karneli, 2018; Ardi \& Sisin, 2018; Misdeni, Syahniar, \& Marjohan, 2015;Arliyus, Neviyarni, Karneli, \& Netrawati, 2019). All members are taught to apply the principles of Rational Emotive Behavior Therapy with the opportunity to practice new behaviors involving risk taking and the application of school discipline. These focuses on Consequences, which is a technique to change the mind of students' disciplinary violations in a variety of real situations (Corey, 2013).

Likewise Bernard \& Digiuseppe (Warren \& Edwin, 2013)explained that the Rational Emotive Behavior Therapy group format was found to reduce irrational beliefs and promote positive mental health. Disciplinary violations arise from students' irrational thoughts, and the central concept of Rational Emotive Behavior Therapy which contributes the most in an individual's life (Holt \& Austad, 2013). The results showed a positive and significant relationship between irrational beliefs on disciplinewith irrational beliefs showed on those with low level of discipline and vice versa(Ningsih, 2015; Khadijah, Marjohan, \& Bentri, 2016).

Rational Emotive Behavior Therapy views students as individuals with shortcomings and limitations, which are overcome to some extent (Winkel \& Hastuti, 2015). According to Ellis (Glading, 2015) students need to try their best to achieve goals of happiness. Based on this opinion, their needs to achieve selfactualization is greatly influenced by thinking, because they are unstable, easily suggestible, and disturbed (Ellis \& Dryden, 2007).

Rational Emotive Behavior Therapy group format is carried out with the primary aim of helping members inculcate rational philosophies of life, similar a series of dogmatic and extreme beliefs originated from their socio-cultural environment (Corey, 2012). The results showed that Rational Emotive Behavior Therapy significantly improve disciplinary problems in large urban secondary schools with the experimental group showing remarkable changes compared to the control (Zelie, Stone, \& Lehr, 1980). Research Diswantika (2016) found significant differences between scores per aspect of the self-discipline of experimental group students before and after receiving treatment in the form of counseling through self-talk techniques in the Rational Emotive Behavior Therapy approach to improve students' self-discipline.

Glading (2015) explained that Rational Emotive Behavior Therapy aims to help group members change their self-destructive thinking or behavior habits. The research findings show group counseling with the Rational Emotive Behavior Therapy approach used to deal with student discipline problems. Ithas the ability to change the irrational beliefs of indisciplined students from external or internal factors into rational beliefs (Amir, 2014). Rational Emotive Behavior Therapy Approach group format is the theory and practice of counseling which is relatively appropriate to improve student discipline.

\section{Conclusion}

In conclusion, discipline is student compliance with regulations relating to their compliance in attending school activities which helps in improving the learning achievement. The results of this study indicate that the overall student discipline at SMAN 2 Padang reached an average percentage of $79.27 \%$ of the ideal score, which indicates that they possess sufficient discipline scores. Therefore, the Rational Emotive Behavior Therapy group format was used to improve and change beliefs, ways of thinking, attitudes, perceptions, and views for students to develop themselves and achieve optimal self-realization. The results of this study serve as a reference for counselors to provide guidance and counseling services to students using a variety of creative and innovative approaches. 


\section{References}

Afdal. (2015). Kolaboratif: Kerangka kerja konselor masa depan. Jurnal Konseling Dan Pendidikan, 3(2), 1-7.

Agustina, L., Daharnis, \& Hariko, R. (2019). Peran konselor dalam meningkatkan disiplin siswa: Tinjauan berdasarkan persepsi siswa. Jurnal Konseling Andi Matappa, 3(1), 15-22.

Allen, K. R., \& Bradley, L. (2015). Career counseling with juvenile offenders: Effects on self efficacy and career maturity. Journal of Addictions \& Offender Counseling, 36(1), 28-42.

Amir, M. A. A. (2014). Pendekatan konseling kelompok rational emotive behavioural therapy dalam meningkatkan kedisiplinan siswa. International in Workshop on Guidance and Counseling, 15(16), 110.

Amri, S. (2013). Pengembangan dan model pembelajaran dalam kurikulum 2013. (M. Jauhar, Ed.). Jakarta: Prestasi Pustaka.

Ardi, Z., \& Sisin, M. (2018). The contribution of assertive technique behavioral counseling to minimize the juvenile delinquency behavior. Jurnal Konseling, 6(2), 67-77.

Ariananda, E. S., Hasan, S., \& Rakhman, M. (2014). Pengaruh kedisiplinan siswa di sekolah terhadap prestasi belajar siswa teknik pendingin. Journal of Mechanical Engineering Education, 1(2), 233-238.

Arliyus, A., Neviyarni, N., Karneli, Y., \& Netrawati, N. (2019). Teori dan aplikasi pendekatan behavioristik dalam konseling. JPGI (Jurnal Penelitian Guru Indonesia), 4(1).

Aulina, C. N. (2013). Penanaman disiplin pada anak usia dini. Jurnal Pedagogia, 2(1), 36-49.

Bechuke, A. L., \& Debeila, J. R. (2012). Applying choice theory in fostering discipline: Managing and modifying challenging learners behaviours in south african schools school of postgraduate studies. International Journal of Humanities and Social Science, 2(22), 240-255.

Corey, G. (2012). Theory \& practice of group counseling. (S. Dobin, Ed.). Canada: Cengage Learning.

Corey, G. (2013). Teori dan praktek: Konseling \& psikoterapi, diterjemahkan oleh E. Koswara. Bandung: Refika Aditama.

Daharnis, Erlamsyah, Ifdil, I., Ardi, Z., \& Hariko, R. (2013). Gambaran kegiatan belajar siswa Sumatera Barat. In International Guidance and Counseling Seminar(Vol. 1).

Dani, N. K. I. P., Suarni, N. K., \& Sulastri, N. M. (2013). Efektivitas konseling behavioral teknik latihan asertif untuk meningkatkan perilaku disiplin belajar siswa kelas X SMA Laboratorium Undiksha tahun 2012/2013. Jurnal IImiah Bimbingan Konseling Undiksha, 1-12.

De Vries, S. L., Hoeve, M., Assink, M., Stams, G. J. J., \& Asscher, J. J. (2015). Practitioner review: effective ingredients of prevention programs for youth at risk of persistent juvenile delinquencyrecommendations for clinical practice. Journal of Child Psychology and Psychiatry, 56(2), 108-121.

Diswantika, N. (2016). Efektivitas teknik self-talk dalam pendekatan konseling kognitif untuk meningkatkan disiplin diri peserta didik. Lentera, 1, 13-31.

Durkheim, E. (1990). Pendidikan moral: Suatu studi teori dan aplikasi sosiologi pendidikan. Jakarta: Erlangga.

Ellis, A., \& Dryden, W. (2007). The practice of rational emotive behavior therapy. New York: Springer Publishing.

Ernawati, R., \& Afdal. (2018). Peningkatan disiplin siswa dalam menaati tata tertib dengan menggunakan teknik modelling melalui layanan penguasaan konten di SMPN 49 Jakarta pada siswa kelas 8 tahun ajaran 2018-2019. Jurnal Selaras, 1(2), 81-95.

Fachrurrozi, Firman, \& Ibrahim, I. (2013). Hubungan Kontrol Diri dengan Disiplin Siswa Dalam Belajar. Jurnal Neo Konseling, 00(00), 1-6.

Fiana, F. J., Daharnis, \& Ridha, M. (2013). Disiplin siswa di sekolah dan implikasinya dalam pelayanan bimbingan dan konseling. Jurnal Ilmiah Konseling, 2(23), 26-33.

Fitri, E., Ifdil, I., \& Neviyarni, S. (2016). Efektivitas layanan informasi dengan menggunakan metode blended learning untuk meningkatkan motivasi belajar. Jurnal Psikologi Pendidikan Dan Konseling: Jurnal Kajian Psikologi Pendidikan Dan Bimbingan Konseling, 2(2), 84-92.

Froggatt, B. W. (2005). Rational emotive behaviour therapy, 1-14.

Geiger, B. (2000). Discipline in K throught 8th grade classrooms. Journal Proques, 121(2), 383.

Glading, S. T. (2015). Konseling: profesi yang menyeluruh. Jakarta: Indeks.

Hamalik, O. (2011). Proses belajar mengajar: Jakarta: Bumi Aksara.

Holt, S. A., \& Austad, C. S. (2013). A comparison of rational emotive therapy and tibetan buddhism: Albert Ellis and the Dalai Lama techniques for change. International Journal of Behavioral Consultation and Therapy, 74), 8-11.

Hurlock, E. B. (2013). Perkembangan anak. Diterjemahkan oleh Meitasari Tjandrasa. Jakarta: Erlangga.

Khadijah, K., Marjohan, \& Bentri, A. (2016). Kontribusi dukungan orangtua dan persepsi siswa tentang disiplin belajar terhadap perilaku membolos serta implikasinya terhadap layanan bimbingan dan onseling. Konselor, 5(3), 172-181.

Khaira, I., Firman, \& Neviyarni, S. (2017). Efektivitas pendekatan rational emotive behavior therapy (REBT) 
dalam meningkatkan penyesuaian sosial anak asuh di Panti Asuhan Wira Lisna Padang. Jurnal Bikotetik, 1(1), $1-7$.

Konadi, H., Mudjiran, M., \& Karneli, Y. (2017). Efektivitas pendekatan rational emotive behavior therapy melalui bimbingan kelompok untuk mengatasi stres akademik siswa. Konselor, 64), 120. Retrieved from http://ejournal.unp.ac.id/index.php/konselor/article/view/7887

Luiselli, J. K., Putnam, R. F., Handler, M. W., \& Feinberg, A. B. (2005). Whole-school positive behaviour support: effects on student discipline problems and academic performance. Educational Psychology, 25(2-3), 183-198.

Misdeni, M., Syahniar, S., \& Marjohan, M. (2019). The effectiveness of rational emotive behavior therapy approach using a group setting to overcome anxiety of students facing examinations. International Journal of Research in Counseling and Education, 3(2), 82-88.

Natalia, N., Firman, \& Daharnis. (2015). Efektivitas layanan informasi dengan menggunakan media audio visual dalam meningkatkan sikap siswa terhadap kedisiplinan sekolah. Jurnal Konseling Dan Pendidikan, 3(2), 40-48.

National Center for Education Statistics. (2018). Indicator 7: discipline problems reported by public schools. IES NCES.

Netrawati, Khairani, \& Karneli, Y. (2018). Upaya Guru BK untuk Mengentaskan Masalah-Masalah Perkembangan Remaja dengan Pendekatan Konseling Analisis Transaksional. Jurnal Bimbingan Dan Konseling Islam, 2(1), 79-90.

Netrawati, N., Karneli, Y., \& Neviyarni, S. (2018). The implementation of basic counseling technique in elementary school for helping the development and alleviating student' s problems in west pasaman district education office. Islamic Counseling: Jurnal Bimbingan Konseling Islam, 2(2), 115-132.

Ningsih, R. (2015). Hubungan persepsi siswa terhadap kedisiplinan dan self-control dengan tingkat kedisiplinan di SMK Karya Rini Yogyakarta. Skripsi Universitas Negeri Yogyakarta.

Pratama, A. H. (2013). Strategi pembentukan disiplin siswa melalui pelaksanaan tata tertib di SMA Negeri 1 Krian Sidoarjo. Jurnal Mahasiswa Undiksa, 1(1), 1-19.

Putra, Y. M. (2012, September). 42 siswa SMAN 6 langgar tata tertib. Antara.

Reski, N., Taufik, T., \& Ifdil, I. (2017). Konsep diri dan kedisiplinan belajar siswa. Jurnal EDUCATIO: Jurnal Pendidikan Indonesia, 3(2), 85-91.

Riyadi, A. (2011). Korelasi antara disiplin belajar dengan prestasi belajar siswa pada mata pelajaran aqidah akhlak kelas VIII di Mts Ma'arif Sikampuh kecamatan Kroya kabupaten Cilacap tahun 2010. Skripsi Walisongo Institutional Reposetory, 54-56.

Sadik, F. (2017). Children and discipline: Investigating secondary school students' perception of discipline through metaphors. European Journal of Educational Research, 6(4), 495-508.

Salgong, V. K., Ngumi, O., \& Chege, K. (2016). The role of guidance and counseling in enhancing student discipline in secondary schools in Koibatek district. Journal of Education and Practice, 713), 142-151.

Semiawan, C. R. (2008). Penerapan pembelajaran pada anak. Jakarta: Indeks.

Susilowati. (2005). Cara Belajar yang efektif dan Efesien. Pekalongan: Cinta Ilmu Pekalongan.

Tu'u, T. (2012). Peran disiplin pada perilaku dan prestasi siswa. Jakarta: Grasindo.

Warren, J. M., \& Edwin R Gerler, J. (2013). Effects of school counselors' cognitive behavioral consultation on irrational and efficacy beliefs of elementary school teachers. The Professional Counselor, 3(1), 6-15.

Winkel, W. S., \& Hastuti, S. (2015). Bimbingan konseling di institusi pendidikan. Yogyakarta: Media Abadi.

Wisnu, Y., \& Kurniawan, S. (2007). Hubungan antara sikap disiplin belajar siswa dan lingkungan belajar siswa dengan prestasi belajar siswa. Skripsi Univesitas Sanata Dharma.

Wulandari, W., Zikra, Z., \& Yusri, Y. (2017). Peran orangtua dalam disiplin belajar siswa. JPGI (Jurnal Penelitian Guru Indonesia), 2(1), 24-31.

Yanti, F., \& Rosalina, M. (2016). Hubungan kedisiplinan dengan prestasi belajar siswa di SMP Maria Immaculata Yogyakarta. Skripsi Univesitas Sanata Dharma.

Zelie, K., Stone, C. I., \& Lehr, E. (1980). Cognitive-behavioral intervention in school discipline: A preliminary study. Personnel \& Guidance Journal, 59(2), 80. 